\title{
Performance based incentives and employees' productivity in commercial organisations
}

\author{
A. M. Ogaboh Agba ${ }^{\text {a,* }}$, T. A. Omang ${ }^{\text {a }}$ C. N. Enukoha ${ }^{a}$, \& Felix O. Eteng ${ }^{\text {b }}$ \\ ${ }^{a}$ Department of Sociology, University of Calabar, Nigeria \\ ${ }^{b}$ Department of Public Administration, University of Calabar, Nigeria
}

\begin{abstract}
The study examined the relationship between performance-based incentives and employees' productivity in commercial organizations in Cross River State, Nigeria. Specifically, the study investigates the links between performance-based incentives such as promotions, bonus, recognition and employees' productivity. Expectancy theory was used to situate the study. Descriptive survey design that allows for the use of questionnaire as quantitative tool was adopted as well as in the selection of respondents from commercial organizations. Quantitative data were analyzed using multi-variance analysis. It was revealed that performancebased promotion, performance-based bonus, performance-based recognition significantly influences productivity of employees in commercial organizations. The study further reveals a joint relationship between the predictor variables (performance-based promotion, bonus, recognition) and productivity of employees. It was recommended among others that promotion policies in commercial organizations should be transparent and fair. Management of these entities should make personnel policies that outline key performance indicators and their relationship to internal promotions, bonuses and wages.
\end{abstract}

Keywords: Performance, incentives, promotions, bonus, recognition, employee productivity.

\section{Introduction}

In an era of increasing competition, business organisations are faced with a greater need to maintain an edge over competitors. Aside other resources, employees are the most important resources that organisations need. They create innovative ideas and implement such to achieve the organisational objectives and goals as well as stay ahead of other competitors (Emeh \& Agba, 2010; Agba, Mboto \& Agba, 2013). Increasingly, business organisations are interested in developing and promoting a committed labour force that will reduce absenteeism and turnover, as well as improve organisational performance and related job attitude. Also, there exist growing body of evidence that workers' positive attitude and discretionary behaviour are vital factors that affect the performance of organisations (Shore, Tetrik, Lynch, \& Barksdale, 2006). Hence the need for a better understanding of the motivational basis for such work-related attitudes.

The management of organisations and labour scholars have recognised incentives as an important tool that motivate employees to put in more effort and carry out their task efficiently and effectively to meet organisational goals (Gana \& Bababe, 2011; Agba \& Ushie, 2010). Suggesting that the absence or lack of appropriate incentive will negatively affect hardworking employees' performance and impede organisational goal attainment (Palmer, 2012; Angioha, Omang, Ishie, \& Iji, 2020). Thus, maximizing the overall organizations' performance requires an understanding of those factors that encourage employees to put in extra effort to enhance their performances (Hafiza, Shah, Jamseheed \& Zaman, 2011; Adah, Angioha, Ugwuonwu, \& Akomaye, 2020). Performance based incentives are one important human resource management strategy for attracting and retaining high-quality employees as well as boosting their performance (Dewhurst, Gutridge \& Mohr, 2010). Appropriate incentive has been recognized as resulting in employees reengineering innovative ideas, as well as getting several tasks completed simultaneously. Empirical

\footnotetext{
* Corresponding author.

E-mail address: ogabohagbagroup@yahoo.com (A. M. Ogaboh Agba)
} 
evidence exists on the effect of performance-based incentives of employee's productivity (Agba, Nkpoyen \& Ushie, 2010; Chipkemoi, 2018; Azin, 2019; Mamdam \& Minhaj, 2016; Agba, Agba \& Nwosu, 2015; Agba \& Ushie, 2010; Enukoha \& Angioha, 2019).

The minimum employees expect from the management of the organisation they work for is fair wages, safe working condition, appropriate incentives and fringe benefits and fair treatment. Like their management or employers, employees also often expect more, depending on their need for increased status, involvement in decision making, increased status and for organizations to address these expectations, proper understanding of employees' motivation is required (Beer, Spector, Lawrence, Mills, \& Walton, 1984).

In Cross River State, Nigeria, as it is in other economies, there is the belief that if business organizations can identify those factors that motivate their labour force besides wages, there will be a drastic reduction of the demand for an increase in wages. Also, less time will be spent on negotiating for increased pay for employees between management and employee unions (Badu, 2010). The general problem inherent in the Cross River State business environment is low salaries, irregular/opaque promotional exercises and lack of recognition of workers' achievements. All these tend to dampen workers' morale and consequently affect their productivity. This study answers the following questions: What effect does performance-based promotion have on employees' productivity in commercial organisations? To what extent does performance based bonus affect employees' productivity in commercial organisations? Does staff recognition have any effect on employees' productivity in commercial organizations? To what extent do the predictor variables (performance-based promotion, bonus and recognition) predict employees' productivity?

\section{Theoretical framework}

The study is built on the expectancy theory developed by Victor Vroom and his associates in 1964 at Yale School of Management. The theory tries to give an explanation on the reason an individual picks a particular behavior over others. It states that effort to act in a particular manner depends on the expectation that the action will lead to an expected outcome and how appealing the outcome is to the person performing the task. According to Vroom, people are motivated to act in a certain way when they believe their actions will lead to an outcome that is desirable. The theory explains the mental process in making a choice to act in a particular way based on motivation.

In organizational settings, the theory proposes that employee job motivation is based on the relationship between the employee output and the outcome from such output based on the calculation of the anticipated outcome (Chen \& Fang, 2008). The expectancy theory is based on three variables; Valence, expectancy and instrumentality. Valence is the relationship between the individual and perceived or expected outcome from a particular behavior. It is the perception not the actual incentive or satisfaction that the employee receive for an output. Expectancy is the belief that more effort will lead to a better performance. Expectancy is influenced by possession of appropriate skills and the presence of the necessary resources for the Job. Instrumentality is the belief that an actual performance will lead to valid reward. This factor is influenced by employees' confidence in their employers, clarity in the relationship between performance and outcome. Thus, the expectancy theory is of the opinion that an individual's motivation to work is based on the how much he/she wants a reward (valence), an assessment of the likelihood that the such effort will lead to an expected performance (expectancy) and that such performance will lead to expected reward (instrumentality) (Vroom, 1964).

\section{Review of Relevant Literatures}

Researchers have documented the relationship between performance based incentives and productivity of workers (Gathungu, Iravo \& Namusonge, 2016; Njanja, Maina, Kibet \& Njagi, 2013; Sitati, Were \& Waitit, 2016; Agba, Akpanudoedehe \& Ocheni, 2014). Gathungu, Iravo and Namusonge (2016) assess the effect of promotion practices on employees' commitment in the banking sector of Kenya. The study applied correlation analysis to analyse data collected from the staff of several commercial banks in Kenya using a self-administered questionnaire. Results reveal a considerable relationship between promotion and workplace commitment at $r=291, p<0.001$, at the 0.01 level of significance. Further analysis revealed that promotion has a negative and significant relationship with commitment $($ Beta $=-0.022$, at $\mathrm{p}>0.05)$. The study recommends a need for an improvement in the promotion criteria and benefit of employees. 
Sitati, Were and Waitit (2016) adopted the survey research design in examining the relationship between employee job promotion and retention in the hospitality industry in Kenya. a sample of 137 respondents was selected from 213 registered hotels in Kenya using a stratified sampling technique. A self-administered structured questionnaire was used to collect data from the respondents. Inferential and descriptive statistics were used to analyse the data. Result revealed a correlation between employee job promotion and job retention in the hospitality industry in Kenya.

Njanja, Maina, Kibet and Njagi (2013) in their study, examined the association between cash bonus and employee performance. The correlation research design was adopted in selecting 68 employees using random sampling. Data was generated using a structured questionnaire and analysed using Chi-Square. Result revealed a significant association between cash bonus and employee job performance. It was recommended that organizations should focus on changing the intrinsic nature and content of jobs. Salah (2016) examine the impact of reward types on the performance of employees. A sample size of 315 was randomly selected from a population of 513 employees working for the unified mining company in southern Jordan. Data collected for the study were analyzed using deceptive statistics such as tables, percentages, mean and standard deviation and Pearson productions moment correlation analysis. Result revealed a significant relationship between rewards types and employee performance

Zaraket and Saber (2017) investigated the correlation between financial reward and job performance. A selfadministered questionnaire was used to collect information from a sample of 250 employees in the contracting, printing and construction industry in Lebanon. Data analysis revealed a significant correlation between financial rewards and job satisfaction. Tausif, (2012) examined the impact of non-monetary reward on job satisfaction among teachers in public schools in Pakistan. Result revealed a significant relationship between non-financial rewards such as recognition and job satisfaction. Murhtar and Nassar (2015) in a study carried out in Malaysia investigated the correlation between reward and job satisfaction. Result revealed a significant relationship between recognition and employee job satisfaction. The study concluded that financial and non-financial reward correlates with job satisfaction.

Magaji, Akpa and Norom, (2018) using structured questionnaire as the instrument of data collection, examine the relationship between recognition, promotion and workplace satisfaction and performance in plateau state. A sample of 541 staff was selected from 5 outsourcing companies using random sampling generated data was analyzed using lineal regression and Pearson product moment correlation result from the analysis of data revealed a significant effect of recognition on job satisfaction and performance.

\section{Methods}

\subsection{Study Setting and Population}

The study was carried out in Cross River State, Nigeria. The state lies between latitude $4^{0} 28^{\prime}$ and $6^{0} 55^{\prime}$ North of the Equator and longitude $7^{0} 50^{\prime}$ and $9^{0} 28^{\prime}$ East of the Greenwich meridian. Cross River state, with a population of over 3 million, the state is located within the tropical rainforest belt of Nigeria and is bounded to the East by the Federal Republic of Cameroun, to the West, Abia and Ebonyi State, Akwa Ibom to the South West and the Atlantic Ocean to the South. Its international boundaries make it a security hotspot and an axis of international trade. The state is home to different business organisation such as both commercial and microfinance banks, cement production factory, telecommunication providers and a flour mill company. The population of the study is employees of selected commercial organizations in Cross River State. The selected commercial organisation includes Flour Mill, Airtel Communication, First Bank, Guaranty Trust Bank and Zenith Bank. The total population of employees in these organizations were 899 .

\subsection{Design and Instrumentation}

The study adopts the descriptive research design. The design allows a study to systematically and accurately describe a situation, phenomenon and population. The design applies different quantitative and qualitative method to examine the correlation between variables (Angioha, Enukoha, Agba, \& Ikhizamah, 2020; Ukwayi, Akintola, \& Angioha, 2019). It was used because of its advantage of producing a good amount of responses from a wide range of people. The method is appropriate to this study since it aims at describing performance-based incentives and attitude of employees. The instrument of data collection was a structured questionnaire (Ojong, Iji, \& Angioha, 2019; Angioha, Nwagboso, Ironbar, \& Ishie, 2018). The instrument (Performance-based incentive and employee productivity 
questionnaire - PBIEPQ) was structured in accordance with the research questions raised. The questionnaire was divided into two (2) units. The first unit contains questions on the performance based incentives (independent variable). The second unit contains questions on employee productivity (dependent variable).

\subsection{Sampling}

The sample used for the study is 270; arrived at using the Survey Monkey Sample Determinant Technique. The sampling technique used for the study is the purposive, proportional stratified and simple random sampling technique. The purposive sampling technique was used in selecting the organizations under study. The purposive sampling was used because of the nature of the study. The purposive sampling technique was used in selecting Flour Mill, Airtel Communication, First Bank, Guaranty Trust Bank and Zenith Bank. The proportional stratified sampling technique was used in selecting the appropriate sample from each of the organizations under study. The sample selection using proportional stratified sampling is highlighted in table 1 and 2. Simple random sampling technique was then used in selecting the needed sample from each of the organization under study.

Table 1. Population Distribution according to Organization

\begin{tabular}{ccccc}
\hline S/N & Commercial & $\begin{array}{c}\text { Population size } \\
\text { Organization }\end{array}$ & $\begin{array}{c}\text { Proportion of } \\
\text { Staff }\end{array}$ & Sample Size (n) \\
\hline 1 & Airtel & 35 & 0.04 & 11 \\
2 & First bank & 259 & 0.29 & 78 \\
3 & Flour Mill & 384 & 0.43 & 115 \\
4 & GTB & 64 & 0.07 & 19 \\
5 & Zenith Bank & 157 & 0.17 & 47 \\
\hline \multicolumn{7}{c}{ Total } & 899 & & 270 \\
\hline
\end{tabular}

Source: Field Work, 2020

Table 2. Sample of Bank Branch

\begin{tabular}{cllccc}
\hline S/N & Bank & \multicolumn{1}{c}{ Branch } & $\begin{array}{c}\text { Bank Branch } \\
\text { Population Size } \\
(\mathrm{N})\end{array}$ & $\begin{array}{c}\text { Proportion } \\
\text { of Staff }\end{array}$ & $\begin{array}{c}\text { Sample } \\
\text { Size (n) }\end{array}$ \\
\hline $1 \quad$ FBN & Calabar Main & 66 & 0.25 & 20 \\
& Obudu & 36 & 0.13 & 11 \\
& OGoja & 17 & 0.06 & 5 \\
& Akamkpa & 15 & 0.05 & 4 \\
& Ekorinim & 17 & 0.06 & 5 \\
& 8miles & 20 & 0.07 & 6 \\
& Main Avenue & 20 & 0.07 & 6 \\
& Ndidem Usang & 32 & 0.12 & 10 \\
& EPZ & 19 & 0.07 & 6 \\
& Iman & 17 & 0.06 & 5 \\
& & $\sum \mathrm{N}=259$ & & $\sum \mathrm{n}=78$ \\
Total & Calabar main & 34 & 0.53 & 10 \\
& Calabar Mariam & 27 & 0.42 & 8 \\
& Ikom & 3 & 0.04 & 1 \\
& & $\sum \mathrm{N}=64$ & & $\sum \mathrm{n}=19$ \\
Total & Mary Slessor & 27 & 0.17 & 8 \\
Zenith Bank & Calabar Main & 53 & 0.33 & 16 \\
& Ikom & 25 & 0.15 & 7 \\
& Ogoja & 26 & 0.16 & 8 \\
& Chamley & 26 & 0.16 & 8 \\
& & 157 & & 47 \\
\hline \multirow{6}{*}{ Total } & & & & \\
\hline
\end{tabular}

Fieldwork, 2020

\subsection{Reliability and Method of Data Analysis}

Cronbach Alpha procedure was adopted to check the internal consistency of the instrument used for data collection. The instrument (Performance-Based Incentive and Employee Productivity Questionnaire (PBIEPQ)) was trial tested on 20 respondents, who do not form part of the original sample size. The instrument reliability measurement ranged from 0.70 to 0.93. Data collected, were coded and inputted into SPSS (Statistical Package for Social Sciences) version 20. Code data were analysed using simple lineal regression at 0.05 confidence level. 
Table 3. Cronbach alpha reliability estimate

\begin{tabular}{lcccc}
\hline \multicolumn{1}{c}{ Variable } & No. of items & Mean & SD & $\begin{array}{c}\text { Cronbach alpha } \\
\text { value (r) }\end{array}$ \\
\hline Performance-based promotion & 4 & 18.64 & 2.96 & 0.75 \\
Performance-based bonus & 4 & 19.41 & 2.85 & 0.74 \\
Performance-based recognition & 4 & 19.42 & 2.39 & 0.70 \\
Employee productivity & 4 & 17.21 & 2.42 & 0.85 \\
Overall scale & 16 & 72.99 & 4.57 & 0.93 \\
\hline
\end{tabular}

\section{Results}

\subsection{Test of hypothesis one}

There is no significant main effect of staff promotion on employees' productivity. The independent variable will be measured in terms of effectiveness, efficiency and performance. To test the hypothesis, Multivariate Analysis of Variance (MANOVA) was adopted in analysing collected data and presented in Table 4.

Table 4. Multivariate analysis of variance of performance-based promotion and employees’ productivity

\begin{tabular}{|c|c|c|c|c|c|c|}
\hline Variable & & $\mathrm{N}$ & Mean & SD & & \\
\hline \multirow{4}{*}{ Staff promotion: } & Effectiveness of employees & 255 & 25.87 & 5.80 & & \\
\hline & Efficiency of employee & 255 & 23.74 & 5.52 & & \\
\hline & Performance of employee & 255 & 26.97 & 5.61 & & \\
\hline & & & 23.91 & 6.03 & & \\
\hline Source & Dependent Variable & $\begin{array}{l}\text { Type III Sum } \\
\text { of Squares }\end{array}$ & df & $\begin{array}{l}\text { Mean } \\
\text { Square }\end{array}$ & $\mathrm{F}$ & Sig. \\
\hline \multirow[t]{3}{*}{ Corrected Model } & Effectiveness & $1058.404^{\mathrm{a}}$ & 3 & 211.681 & 7.403 & .000 \\
\hline & Efficiency & $594.867^{\mathrm{b}}$ & 3 & 118.973 & 4.781 & .001 \\
\hline & Performance & $791.681^{c}$ & 3 & 158.336 & 5.091 & .000 \\
\hline \multirow[t]{3}{*}{ Productivity } & Effectiveness & 925.374 & 1 & 925.374 & 27.231 & $.000 *$ \\
\hline & Efficiency & 560.607 & 1 & 560.607 & 22.526 & $.000^{*}$ \\
\hline & Performance & 615.114 & 1 & 615.114 & 32.012 & $.000^{*}$ \\
\hline \multirow[t]{3}{*}{ Error } & Effectiveness & 3259.521 & 251 & 28.592 & & \\
\hline & Efficiency & 2837.100 & 251 & 24.887 & & \\
\hline & Performance & 3545.486 & 251 & 31.101 & & \\
\hline \multirow[t]{3}{*}{ Total } & Effectiveness & 63859.000 & 255 & & & \\
\hline & Efficiency & 56436.000 & 255 & & & \\
\hline & Performance & 72978.000 & 255 & & & \\
\hline
\end{tabular}

The results of the Multivariate Analysis of Variance (MANOVA) for this hypothesis is presented in Table 4. As shown in the upper part of the Table, the mean scores for the sub-variables of employees' productivity: employees' effectiveness, efficiency and performance are $(\bar{X}=25.81 ; \mathrm{SD}=5.50 ; \bar{X}=23.74, \mathrm{SD}=5.52$; and $\bar{X}=26.97, \mathrm{SD}=$ 5.61 ), the mean scores revealed that staff promotion affects employee performance more than other sub-variables of productivity.

As shown in Table 4, the calculated F-values for employees productivity: employee effectiveness, $\mathrm{F}(1,251)=32.364$; employee efficiency, $\mathrm{F}(1,251)=22.526$; employee performance $\mathrm{F}(1,251)=19.778$ are each greater than the critical F-value of 3.00 at 1 and 251 degrees of freedom, and 0.05 level of significance. With these results, the null hypothesis which states that there is no significant main effect of staff promotion on employees' productivity in terms of effectiveness, efficiency and performance in commercial organisations was rejected and the alternate hypothesis accepted. It was concluded that; there is a statistically significant main effect of staff promotion on employee productivity: effectiveness, efficiency and performance.

\subsection{Test of hypothesis two}

There is no significant main effect of performance-based bonus on employees' productivity. The dependent variable was measured in terms of effectiveness, efficiency, and performance. To test the hypothesis, Multivariate analysis of variance (MANOVA) was used to analyse the data and the result is presented in Table 5. 
Agba et.al | Quantitative Economics and Management Studies (QEMS), 2021, 2(2): 129-139

Table 5. Multivariate analysis of variance of performance-based bonus and employees' productivity

\begin{tabular}{|c|c|c|c|c|c|c|}
\hline Variable & & $\mathrm{N}$ & Mean & SD & & \\
\hline \multirow{4}{*}{$\begin{array}{l}\text { Performance } \\
\text { based bonus }\end{array}$} & Effectiveness of employees & 255 & 26.12 & 5.06 & & \\
\hline & Efficiency of employees & 255 & 25.59 & 6.65 & & \\
\hline & Performance of employees & 255 & 25.87 & 5.80 & & \\
\hline & & & 19.11 & 5.42 & & \\
\hline Source & Dependent Variable & $\begin{array}{l}\text { Type III Sum } \\
\text { of Squares }\end{array}$ & df & $\begin{array}{l}\text { Mean } \\
\text { Square }\end{array}$ & $\mathrm{F}$ & Sig. \\
\hline \multirow[t]{3}{*}{ Corrected Model } & Effectiveness & $1048.656^{\mathrm{a}}$ & 3 & 209.731 & 8.782 & .000 \\
\hline & Efficiency & $304.706^{\mathrm{b}}$ & 3 & 60.941 & 2.995 & 015 \\
\hline & Performance & $242.813^{c}$ & 3 & 48.563 & 1.919 & .099 \\
\hline \multirow{3}{*}{ Productivity } & Effectiveness & 1009.922 & 1 & 1009.922 & 12.180 & $.044 *$ \\
\hline & Efficiency & 85.048 & 1 & 85.048 & 9.675 & $.028^{*}$ \\
\hline & Performance & 93.004 & 1 & 93.004 & 7.999 & $.021 *$ \\
\hline \multirow[t]{3}{*}{ Error } & Effectiveness & 2101.556 & 251 & 23.881 & & \\
\hline & Efficiency & 1790.571 & 251 & 20.347 & & \\
\hline & Performance & 2227.187 & 251 & 25.309 & & \\
\hline \multirow[t]{3}{*}{ Total } & Effectiveness & 51234.000 & 255 & & & \\
\hline & Efficiency & 51088.000 & 255 & & & \\
\hline & Performance & 66014.000 & 255 & & & \\
\hline
\end{tabular}

The results of the Multivariate Analysis of Variance (MANOVA) for this hypothesis is presented in Table 5. As shown in the upper part of the Table, the mean scores for the sub-variables of employees' productivity: employees' effectiveness, efficiency and performance are $(\bar{X}=26.12 ; \mathrm{SD}=5.06 ; \bar{X}=25.59, \mathrm{SD}=6.65$; and $\bar{X}=25.87, \mathrm{SD}=$ 5.80 ), the mean scores revealed that performance based bonus affect employee effectiveness more than other subvariables of productivity.

As shown in the Table, the calculated F-values for employees productivity: employee effectiveness, $\mathrm{F}(1,251)=$ 12.80; employee efficiency, $\mathrm{F}(1,251)=9.675$; employee performance $\mathrm{F}(1,251)=7.999$ are each greater than the critical F-value of 3.00 at 1 and 251 degrees of freedom, and 0.05 level of significance. With these results, the null hypothesis which states that there is no significant main effect of performance based bonus on employees' productivity in terms of effectiveness, efficiency and performance in commercial organisations in Cross River State, Nigeria was rejected and the alternate hypothesis accepted. It was concluded that there is a statistically significant main effect of staff promotion on employee productivity: effectiveness, efficiency and performance. This suggests that performance based bonus can effectively promote/increase employee productivity in terms of effectiveness, performance and efficiency in this order.

\subsection{Test of hypothesis three}

There is no significant main effect of staff recognition on employees' productivity in terms of effectiveness, efficiency and performance in commercial organization in Cross River State, Nigeria. The dependent variable is measured in terms of effectiveness, efficiency and performance. To test the hypothesis, Multivariate Analysis of Variance (MANOVA) was used to analyse the data and the result is presented in Table 6.

Table 6. Multivariate analysis of variance of performance-based staff recognition and employees' productivity

\begin{tabular}{lllllll}
\hline Variable & & N & Mean & SD & & \\
\hline Performance-based & Effectiveness of & 255 & 23.20 & 5.85 & & \\
staff recognition & employees & Efficiency of employee & 255 & 24.36 & 5.18 & \\
& Performance of employee & 255 & 23.74 & 5.52 & & \\
& & & 22.76 & 4.11 & & \\
\hline Source & Dependent Variable & $\begin{array}{l}\text { Type III Sum } \\
\text { of Squares }\end{array}$ & df & $\begin{array}{l}\text { Mean } \\
\text { Square }\end{array}$ & F & Sig. \\
& & $1053.287^{\mathrm{a}}$ & 3 & 209.731 & 8.782 & .000 \\
\hline Corrected Model & Effectiveness & $324.510^{\mathrm{b}}$ & 3 & 60.941 & 2.995 & .015 \\
& Efficiency & $272.374^{\mathrm{c}}$ & 3 & 48.563 & 1.919 & .099
\end{tabular}




\begin{tabular}{|c|c|c|c|c|c|c|}
\hline Variable & & $\mathrm{N}$ & Mean & SD & & \\
\hline \multirow[t]{3}{*}{ Productivity } & Effectiveness & 3.225 & 1 & 1009.922 & 4.963 & $.009 *$ \\
\hline & Efficiency & 19.443 & 1 & 85.048 & 8.697 & $.021 *$ \\
\hline & Performance & 28.728 & 1 & 93.004 & 5.852 & $.037 *$ \\
\hline \multirow[t]{3}{*}{ Error } & Effectiveness & 2096.926 & 251 & 23.881 & & \\
\hline & Efficiency & 1770.766 & 251 & 20.347 & & \\
\hline & Performance & 2197.626 & 251 & 25.309 & & \\
\hline \multirow[t]{3}{*}{ Total } & Effectiveness & 51234.000 & 255 & & & \\
\hline & Efficiency & 51088.000 & 255 & & & \\
\hline & Performance & 66014.000 & 255 & & & \\
\hline
\end{tabular}

The results of the Multivariate Analysis of Variance (MANOVA) for this hypothesis is presented in Table 6. As shown in the upper part of the Table, the mean scores for the sub-variables of employees' productivity: employee effectiveness, efficiency and performance are $(\bar{X}=23.20 ; \mathrm{SD}=5.85 ; \bar{X}=24.36, \mathrm{SD}=5.18$; and $\bar{X}=23.74, \mathrm{SD}=$ 5.52). The mean scores revealed that performance based bonus affect employee effectiveness more than other subvariables of productivity.

As shown in the table the calculated F-values for employees productivity: employee effectiveness, $\mathrm{F}(1,251)=4.963$; employee efficiency, $\mathrm{F}(1,251)=8.697$; employee performance $\mathrm{F}(1,251)=5.852$ are each greater than the critical $\mathrm{F}$ value of 3.00 at 1 and 251 degrees of freedom, at 0.05 level of significance. With these results, the null hypothesis which states that there is no significant main effect of performance-based staff recognition on employees' productivity in terms of effectiveness, efficiency and performance in commercial organisations in Cross River State, Nigeria is rejected and the alternate hypothesis accepted. It was concluded that there is a statistically significant main effect of staff recognition on employee productivity: effectiveness, efficiency and performance. It suggests that staff recognition can effectively promote/increase employee productivity in terms of efficiency, performance and effective in this order.

\subsection{Test of hypothesis four}

There is no significant joint contribution of the predictor variables (promotion, performance-based bonus and recognition) on the productivity of employees' in commercial organizations.

Table 7. Regression Model Summary of all the predictor variables: performance-based promotion, performance-based bonus and performancebased recognition on the productivity of employees

\begin{tabular}{|c|c|c|c|c|c|}
\hline Model & $\mathrm{R}$ & $\mathrm{R}$ square & $\begin{array}{c}\text { Adjusted R } \\
\text { square }\end{array}$ & $\begin{array}{l}\text { Std error of } \\
\text { the estimate }\end{array}$ & \\
\hline 1 & .533 & .284 & 0.279 & 6.39696 & \\
\hline $\begin{array}{c}\text { Source of } \\
\text { Variance }\end{array}$ & $\begin{array}{l}\text { Sum of } \\
\text { Squares }\end{array}$ & df & $\begin{array}{l}\text { Mean } \\
\text { square }\end{array}$ & $\mathrm{F}$ & Sig. \\
\hline Regression & 14297.120 & 3 & 2042.446 & 49.912 & $.000 *$ \\
\hline Residual & 35969.691 & 251 & 40.921 & & \\
\hline Total & 50266.812 & 254 & & & \\
\hline
\end{tabular}

As presented in Table 7, the regression model summary, and ANOVA, shows that the predictor variables had a moderate positive correlation with the productivity of employees' in commercial organisations $(\mathrm{R}=.533, \mathrm{p}<.05)$. The combination of all the predictor variables (promotion, performance-based bonus and recognition) is joint predictors of productivity of employees'. Overall, the model accounts for $28.4 \%$ of the variance in productivity of employees and is a significant fit of the data (or, put another way, the $28.4 \%$ of variance that can be explained is a significant amount).

Also, the ANOVA shows a moderate lineal joint relationship (contribution) of all the predictors to the productivity of employees given by the F-ratio $(3,251)=49.912 ; \mathrm{p}<0.05$. the interpretation implies that the model statistical significantly improves the researchers' ability to predict the outcome variable (as a result of the F-ratio being significant). The adjusted $\mathrm{R}^{2}(0.279)$ revealed shrinkage of the unadjusted value (0.284), which implies that the model is suitable for use to generalise the population. From this result, it was revealed that when all the predictor variables 
(promotion, performance-based bonus and recognition) are used together, the productivity of employee in commercial organisations will significantly improve.

\section{Discussion of Findings}

There is a statistically significant main effect of staff promotion on employees' productivity in commercial organisations in Cross River State, Nigeria. This result implies that staff promotion can effectively promote/increase employees' productivity in terms of performance, effectiveness and efficiency in this order. The findings of this study are supported by the findings of Gathungu, Iravo and Namusonge (2016), Noraani, and Zaizura (2013), Muhammad, Rizwan, and Yasin (2012), Sitati, Were and Waitit (2016) and Adnan and Mahazril 'Aini (2011). Gathungu, Iravo and Namusonge (2016), posit that promotion has a negative and significant relationship with commitment. Similarly, Sitati, Were and Waitit (2016) Posit that there is a positive and significant relationship between job promotion and employee retention in the hotel industry.

More so, the study revealed that there is a statistically significant main effect of performance based bonus on employee productivity in commercial organizations in Cross River State, Nigeria. The result implies that performance based bonus can effectively promote/increase employees' productivity in terms of effectiveness, performance and efficiency in this order. It reveals that performance based bonus affect employee effectiveness more than other subvariables of productivity. The findings corroborated the works of Njanja, Maina, Kibet and Njagi, (2013); Salah, (2016); Zaraket and Saber, (2017). Njanja, Maina, Kibet and Njagi (2013) argued that cash bonus does not affect employee performance. This is because, those who received cash bonuses and those who did not belief that the cash bonus affects their performance the same. Similarly, Salah (2016) observed that there is a statistical significant relationship between rewards types and employees' performance.

Again, the study showed that there is a statistically significant main effect of staff recognition on employee productivity in commercial organizations in Cross River State, Nigeria. This result implies that staff recognition can effectively promote/increase employees' productivity in terms of efficiency, performance and effective in this order. It reveals that performance based bonus affect employee effectiveness more than other sub-variables of productivity. These findings are similar to that of Tausif, (2012) Mokhtar and Nasser (2015) and Magaji, Akpa and Norom, (2018). For instance, Tausif, (2012) examined the impact of non-monetary reward on job satisfaction among teachers in public schools in Pakistan. Result revealed a significant relationship between non-financial rewards such as recognition and job satisfaction and performance enhancement. Also, Mokhtar and Nasser (2015) investigated the correlation between reward and job satisfaction. Result revealed a significant relationship between recognition and employee job satisfaction.

\section{Conclusion and recommendations}

This study sought to examine the relationships between performances based incentives and employees' productivity in commercial organizations in Cross River State, Nigeria. The study specifically examined promotion, performancebased bonus, recognition and their relationship with employees' productivity in commercial organizations. From the analysis, results revealed that there is a significant relationship between performance-based promotion, performancebased bonus recognition and employees' productivity in commercial organizations. The study concludes that there is a significant relationship between performance-based incentives and employees' productivity in commercial organizations in Cross River State, Nigeria. Based on these findings, the following recommendations were made:

1) Promotion policies of commercial organizations should be transparent and fair. These policies should be well communicated to employees. It should outline clearly the key performance indicators and its relationship to internal promotions, performance-based bonuses and recognition.

2) Commercial organizations should give serious thought to increasing employees' wages based on their performance and other remunerations.

3) Non-financial rewards such as recognition and commendation should be used by management as a vital motivational tool for workers. 


\section{References}

Adah, J. A., Angioha, P. U., Ugwuonwu, C. V., \&Akomaye, S. (2020), “An Empirical Analysis of the Relationship between Working Condition and the Effectiveness of Employees in Commercial Banks in Cross River State" Journal of Banking and Finance Management, 3(2), 2020, pp. 18-24.

Adnan, A. \& Mahazril 'Aini, Y. (2011). The Effects of Recruitment and Promotion Practices on Employees' Job Satisfaction in the Local Governments. Voice of Academia, 6 (1), 238-248

Angioha, P. U., Enukoha, C. U., Agba, R. U., \& Ikhizamah, G. U. (2020). Information Technology Predictor Variables and Employee Productivity in Commercial Banks. JINAV: Journal of Information and Visualization, 1(1), 44-52. https://doi.org/10.35877/454RI.jinav178

Angioha, P. U., Nwagboso, S. N., Ironbar, A. E. \& Ishie, E. U. (2018). Underemployment: A Sociological and Policy Analysis of Workers Well-Being in Hospitality Industry in Calabar, Cross River State, Nigeria. IOSR Journal of Humanities and Social Science (IOSR-JHSS), Volume 23, Issue 6, Ver. 5 (June. 2018) PP 57-66.

Angioha, P. U., Omang, T. A., Ishie, E. U., \& Iji, M. E. (2020)., "Employee Stressors and Wellbeing of Healthcare Workers in Government owned Hospitals in Calabar, Nigeria", Journal of Public Administration, 2(4), 2020, pp. 36-43

Agba, A. M. O., Agba, M. S. \&Nwosu, U. W. (2015). Global trends of wage and income inequality: Lessons for Nigerian employerse ${ }^{\text {ee }}$ and economic planners. International Journal of Public Administration and Management Research (IJPAMR), 3(1), pp. 17-28,

Agba, A. M. O., Mboto, W. A. \& Agba, M. S. (2013). Wages or other Conditions: A critical Assessment of Factors in Workers Performance in Nigeria. International Journal of Academic Research in Business and Social Sciences, 3(7), 489-505.

Agba, A. M. O. Nkpoyen, f. \& Ushie, E. M. (2010),“Career development and employee commitment in industrial organizations in Calabar, Nigeria”. American Journal of Scientific and Industrial Research, Vol. 1 Issue 2, pp. 105-114.

Agba, A. M. O., Akpanudoedehe, J. J. \& Ocheni, S. (2014). Financing Poverty Reduction Programmes in Rural Areas of Nigeria: The Role of Non-Governmental Organizations (NGOs). International Journal of Democratic and Development Studies (IJDDS), Vol. 2, No. 1, Pp. 1-16.

Agba, A. M. O., \& Ushie, E. M. (2010). Motivational Incentives and Staff Turnover in the Hospitality Industry in Cross River State, Nigeria. Global Journal of Management and Business Research, 10 (8), 18-28.

Agba, A. O. M. \& Ushie, E. M. (2010). Managing Employee-employer Relations for increased Industrial Peace and Harmony in the Workplace. Labour Law Review: Nigerian Journal of Labour Law and Industrial Relations, 4(2), Pp. 73-83.

Azasu, S. (2004). Using Pay and Benefits in a Swedish Real Estate Firm. Retrieved $10^{\text {th }}$ august 2019 from http://eres.scix.net/data/works/att/db82.content.00379.pdf

Aziri,J. (2019). Employee Motivation Incentives and Their impact on the Organization's Productivity. Texila International Journal of Management, 5(2), 1-6.

Block, R. H., \& Lagasse, D. R. (1997). Making a bonus plan work for you. HR Magazine, 1. Retrieved from 8 august 2019 http://findarticles.com

Chen, Y.-Y., \& Fang, W. (2008). The moderating effect of impression management on the organizational politicsperformance relationship. Journal of Business Ethics, 79(3), 263-277. https://doi.org/10.1007/s10551-007-9379-3

Chepkemoi, J. (2018). Effect of Incentives on Employee Performance At Kenya Forest Service Uasin Gishu County. IOSR Journal of Business and Management (IOSR-JBM). 20(3), PP 26-32

Danish, R. Q. \& Usman A. (2010). Impact of reward and recognition on job satisfaction and motivation: an empirical study from Pakistan. International Journal of Business and Management 5 (2), 159-167. 
Dewhurst, M., Guthridge, M. \& Mohr, E. (2009). Motivating people: Getting beyond money. McKinsey quarterly Available online at http://veruspartners.net/private/app/webroot/ les/mota09.pdf

Elumah, L. O., Ibrahim, O. M. \& Shobayo, P. B. (2016). The Impact of Financial and Moral Incentives on Organizational Performance. A Study of Nigerian Universities. Arabian J Bus Manag Review, 6(5) 1-7.

Emeh, J. U. \& Agba, A. M. O. (2010). Professionalizing Teaching in Nigeria for effective service delivery and National Development. European Journal of Social Sciences, 17(3):352-359

Enukoha, C. U. \& Angioha, P. U. (2019). "Management Support for the Use of Information technology in Commercial Banks in Cross River State, Nigeria: Examining Its Relationship with the Productivity of Workers", Journal of Banking and Finance Management, 2(3), pp.1-7

Finkle, L. (2011). Motivating Employee Performance through Year End Bonuses. Retrieved $6^{\text {th }}$ May from http://ezinearticles.com/?Motivating-Employee-Performance-Through-Year-End-Bonuse\&id.5658825

Gathungu, E.W. M., Iravo, M. A. \& Namusonge, G.S. (2016). Effect of Promotion Strategies on the Organizational Commitment of Banking Sector Employees in Kenya. IOSR Journal of Humanities and Social Science (IOSR-JHSS), 20(10), 36-45.

Jeffrey, S. \& Shaffer, V. (2007). The Motivational Properties of Tangible Incentives. Sage Publications.

Kinicki, A. J., Jacobson, K. J. L., Galvin, B. M., \& Prussia, G. E. (2011). A multilevel systems model of leadership. Journal of Leadership \& Organizational Studies, 18(2): 133-149.

Luthans, K. (2000). Recognition: A Powerful, but Often Overlooked, Leadership Tool to Improve Employee Performance. Journal of Leadership Studies, 7(1), 31-39.

Magaji, N., Akpa, V. O \& Norom, G. K. (2018). Effect of Recognition and Promotion on Employees' Job Satisfaction of Selected Outsourced Service Providers in Jos, Plateau State, Nigeria. International Journal of Business and Management 20(9):60-68.

Mamdani, K. F. \& Minhaj, S. (2016). Effects of Motivational Incentives on Employees' Performance: A Case Study of Banks of Karachi, Pakistan. South-East Asia Journal of Contemporary Business, Economics and Law, 9(2), 32-39.

Mamdani, K., \& Minhaj, S. (2016). Effects of motivational incentives on employees' performance: A case study of banks of Karachi, Pakistan. South East Asia Journal of Contemporary Business, Economics and Law, 9(2), $32-39$

Mamik,A., Apriantoro, N. H. \& Luthfiyah, S. (2016). Correlation of Incentive and Reward to Improve Employee Performance and Job Satisfaction at Operating Paper Mill in East Java Indonesia. International Review of Social Sciences and Humanities, 10, (2),. 90-97

Milgrom, P. \& Roberts, J. (1992). Economics, Organization and Management, Englewood Cliffs, NJ: Prentice Hall.

Mokhtar, A. \& Nasser, H. (2015). Reward system and job satisfaction: A conceptual review. Global Advanced Research Journal of Management and Business Studies (4), 137-141.

Muhammad, E. M., Rizwan, Q. D. \& Yasin M. (2012). The Impact of Pay and Promotion on Job Satisfaction: Evidence from Higher Education Institutes of Pakistan. American Journal of Economics, Special Issue: 6-9.

Njanja, W. L., Maina, R. N. , Kibet, L. K. \& Njagi, K. (2013). Effect of Reward on Employee Performance: A Case of Kenya Power and Lighting Company Ltd., Nakuru, Kenya. International Journal of Business and Management; 8(21), 41-49.

Noraani, M. \& Zaizura, C. Z. (2013). The Effect of Promotion Opportunity in Influencing Job Satisfaction among Academics in Higher Public Institutions in Malaysia. International Journal of Academic Research in Business and Social Sciences, 3, (3), 20-26. 
Nwude, E. C. \& Uduji, J. I. (2013). An Analysis of How Prospect for Promotion Affects Job Performance in the Federal Teaching Hospitals in Nigeria. Public Policy and Administration Research, 3, (3), 46-58

Ojong, M. U., Iji, M. E., Angioha, P.U. (2019). Curing Socio-Economic ILLS in Obudu Local Government Area: An Assessment of Non-Governmental Agencies Activities". Journal of Social Service and Welfare;1(2): 38-45.

Randy, K., Luk, V.W. \& Tang, L. P. (1998). Retaining and motivating employees: Compensation preferences in Hong Kong and China. Paper presented at the Inaugural conference of the Asia academy of management.

Robbins, S.P. (2005). Organization behaviour (11th ed.). New Delhi: Pretence Hall of India Private Ltd.

Romano, L. (2003). Beyond Reward: Why Cash is no Longer Enough. Rewards, 3(1), 12-13

Salah, M. S. A. (2016). The Influence of Rewards on Employees Performance. British Journal of Economics, Management \& Trade, 13(4): 1-25,

Saunders, M., Lewis, P. \& Thornhill, A. (2007). Research Methods for Business Students, (4th ed.), Pearson Education Ltd, Harlow, England.

Sitati, N., Were, S. \& Waitit, G. A. (2016). Effects of Job Promotion on Employee Retention in Hotels in Kenya. The Strategic Journal of Business \& Change Management, 3, 4 (51), 956-972.

Ukwayi, Joseph K., Akintola, Abayomi \& Angioha, Pius U (2019); Biometric Security In Business Organisation: An Assessment Of Its' Impact On Checking Corporate Crime In Business Organizations In Cross River State Nigeria; International Journal of Scientific and Research Publications (IJSRP) 9(5) (ISSN: 2250-3153), DOI: http://dx.doi.org/10.29322/IJSRP.9.05.2019.p8966

Tessema, M. T., Ready, K. J. \& Embaye, A. B. (2013). The Effects of Employee Recognition, Pay, and Benefits on Job Satisfaction: Cross Country Evidence. Journal of Business and Economics, 4(1), 1-12

Vroom, V. (1964). Work and motivation. New York, NY: Wiley.

Zaraket, W. S. \& Saber, F. (2017). The Impact of Financial Reward on Job Satisfaction and Performance: Implications for Blue Collar Employees. China-USA Business Review, 16(8), 369-37 